\title{
Leibniz: el abogado de Dios
}

\author{
Martha Massa
}

\author{
G. Deleuze, El Pliegue. Leibniz y el barroco. \\ Barcelona, Paidós, 1989
}

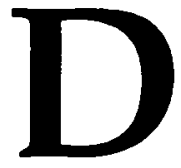

efender la causa de Dios. Salvar el ideal teológico en el momen. to en que el mundo lo combate desde todas partes y no cesa de acumular pruebas en su contra. Contrarrestar la crisis psicótica que, en la cresta de su ola, niega todo principio y toda ley. Responder a la miseria del mundo manteniendo algo más bien que nada. Esas son, desde la perspectiva deleuziana, las razones que tuvo Leibniz para reconstruir el mundo, para convertirlo en "el mejor de los mundos posi. bles", mediante un sistema concebido en el más puro estilo barroco. Más que eso, mediante un sistema que conceptualiza el Barroco. Un sistema en el que proliferan los principios, en el que nada queda al Azar, y en el que se conjura el vacío mediante pliegues, repliegues y despliegues, en un esfuerzo inusitado por no devolver nada a la ausencia.

Con una cultura filosófica y artística comparable sólo con la dimensión de su talento, Deleuze da por supuesto que sus lectoras y lectores reconocen en el arte barroco esa intención de conciliar el impulso hacia lo ilimitado, que despertaba la concepción del mundo infinito basada en el descubrimiento de Copérnico, con la fe renovada, exacerbada, que trajeron consigo la Reforma y la Contrarreforma. Supone también que los lectores reconocen que Leibniz compartía plenamente esa intención. Que la física matemática que él mismo revoluciona, es sólo un instrumento para establecer una ley de la continuidad que permita a lo sensible y a lo inteligible formar parte de un solo mundo, en el que Dios recupera la condición espiritual que el spinozismo le negaba.

Son estos supuestos los que le dan plena plausibilidad a esta versión, inexplicablemente insospechada, de un barroco leibniziano, que Deleuze recrea prodigiosamente en el libro que aquí, más que comentar, recomendamos. En él, el sistema leibniziano se comprende por analogía con la arquitectura, la escultura, la pintura, la danza y la música barrocas. Se trata de un 
sistema que, cuando la razón clásica se desintegra a causa de las divergencias, incomposibilidades, desacuerdos y disonancias, aparece como la última tentativa de reconstruir esa razón, distribuyendo las divergencias en otros mundos posibles, convirtiendo los incomposibles en fronteras entre los mundos, resolviendo los desacuerdos en acordes, conciliando la continuidad de la extensión con la individualidad más plena y condensada.

A su vez, el arte barroco encuentra su concepto en el pliegue leibniziano: pliegue que va hasta el infinito. Pliegue que atraviesa las materias -mármol, granito, lienzo- para proyectar formas asignables -cuerpos, rocas, nubes, aguas-, que ya no se explican por las materias que los constituyen, sino por la presencia espiritual que los ilumina, y por la armonía que los inserta en un teatro universal, donde las esculturas son los verdaderos personajes, la ciudad es un decorado, y los espectadores son ellos mismos imágenes pintadas o esculturas.

Pero hay algo más allá de esta recreación -o creación- del barroquismo de Leibniz. Con su peculiar estilo de entretejer su propio pensamiento con las obras filosóficas y artísticas que le entusiasman, Deleuze hace del pliegue infinito, del pliegue leibniziano, un concepto operativo que, por romper cualquier restricción genérica o temporal que se imponga al Barroco, no sólo se vuelve un concepto capaz de aplicarse por igual a músicos, poetas, arquitectos, pintores, escritores o filósofos, sino que permite descubrir, en la filosofía y en las artes, un neobarroco que despliega incomposibilidades, divergencias y diferencias en el mismo mundo, que emancipa la disonancia y los acordes no resueltos.

Para el surgimiento de ese neobarroco o ese neoleibnizianismo, dice Deleuze, ha hecho falta que la razón kantiana muera por neurosis, y que ceda el paso a un pensar sin principios que, en ausencia de Dios y del hombre, afirma el Azar y la Nada más bien que algo.

Tal es el neobarroco deleuziano. 